\title{
Immune Functions in Males and Females: Does the Hormones Play The Role?
}

Somenath Ghosh*

Assistant Professor, Post Graduate Department of Zoology, Rajendra College, Chapra-841301, Bihar, India

DOI: $\underline{10.36347 / \text { sajp.2020.v09i07.005 }}$

| Received: 12.07.2020 | Accepted: 20.07.2020 | Published: 21.07.2020

*Corresponding author: Somenath Ghosh

\section{Abstract}

The open circuit system of immunity is composed of different cellular and non-cellular components. But the components are seemingly limited in view of their multi-faceted actions. Hence, the particularity and functional diversity of immune system lies in the mode of regulation of all of its components. There are different factors which regulate the proper function and modus operandi of several components of immune system. Among them one most important factor is regulation via hormones. There are different classes of hormones, but in context of immune system, hormones are immune-enhancing, immune-inhibitory or immune-neutral. In depth studies have shown that response of immune system varies with hormones of different kinds. It depends upon the context (in vivo and in vitro), nature of hormone (steroid, proteinaceous, peptide, amino acid and/ amino acid derivative), body condition (healthy vs. under pathological/clinical) and their behavior when in combination with other hormones and in contact with cellular and non-cellular components of immune system. It is notable that males and females of any animal differ physiologically and one of the reasons behind different physiology is involvement of hormones. Thus, it is a matter of investigation how gender wise differentiation exists at immunological level. Till date very little is known in this aspect and in depth molecular studies are on the way to explore out the reason. This review, however in brief encompasses the dimorphism of immunity and immune response in terms of gender under hormonal regulation.

Keywords: Dimorphism, Gender, Hormone, Immunity.

Copyright @ 2020: This is an open-access article distributed under the terms of the Creative Commons Attribution license which permits unrestricted use, distribution, and reproduction in any medium for non-commercial use (NonCommercial, or CC-BY-NC) provided the original author and source are credited.

\section{INTRODUCTION}

The immune system is composed of many interdependent cell types that collectively protect the body from bacterial, parasitic, fungal, viral infections and from the growth of tumor cells. Many of these cell types have specialized functions. The cells of the immune system can engulf bacteria, kill parasites or tumor cells, or kill viral-infected cells. Often, these cells depend on the $\mathrm{T}$ helper subset for activation signals in the form of secretions formally known as cytokines, lymphokines, or more specifically interleukins.

Immunity is divided into two parts determined by the speed and specificity of the reaction. These are named the innate and the adaptive responses, although in practice there is much interaction between them. The term innate immunity is sometimes used to include physical, chemical and microbiological barriers, but more usually encompasses the elements of the immune system (neutrophils, monocytes, macrophages, complement, cytokines, and acute phase proteins) which provide immediate host defence. The highly conserved nature of the response, which is seen in even the simplest animals, confirms its importance in survival [1]. Adaptive immunity is the hallmark of the immune system of higher animals. This response consists of antigen-specific reactions through $T$ lymphocytes and B lymphocytes. Whereas the innate response is rapid but sometimes damages normal tissues through lack of specificity, the adaptive response is precise, but takes several days or weeks to develop. The adaptive response has memory, so that subsequent exposure leads to a more vigorous and rapid response, but this is not immediate [2]. The basic architecture of the immune system can be depicted as follows: 


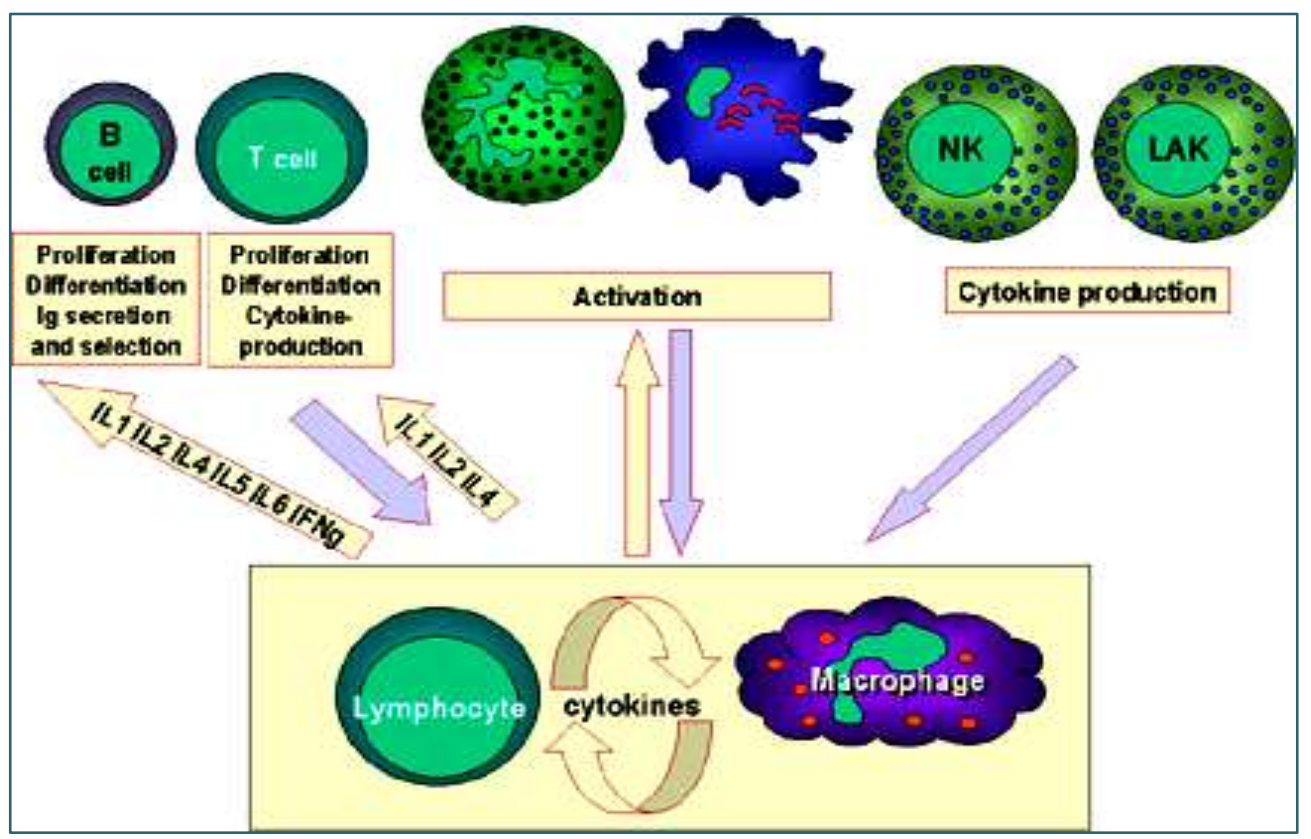

Fig-1: (Photo courtesy: Nature Reviews Immunology, 2009) [3]

Thus, from the above mentioned information it is clear that immune system which plays most vital role in physiology and survival is composed of very small number of components cellular or non-cellular). Hence, functional diversity of this system lies in its types of factors regulate its function.

\section{Factors Regulating Immune Modulation Effect of Sex and Sexual Dimorphism in Immune Function}

Immune responses are sexually dimorphic, both in type and magnitude. Two general systems of immunity to infectious agents have been selected during evolution- innate (natural) immunity and acquired (adaptive or specific) immunity. The innate immune system uses proteins encoding the germ line (on macrophages, mast cells, natural killer cells) to recognize conserved products ofinfectious non-self (i.e., microbial pathogens), but not non-infectious self i.e. host proteins [4]. Sex differences in mortality and immune competence are well documented in humans. Women in most societies not only have longer life spans, they also are more resilient against infectious and some non-infectious diseases such as cancer [5]. This, however, comes at the price of women being more susceptible to autoimmune diseases [6]. These effects are commonly attributed to sexual differences in endocrinology.

The phenomenon of higher female immune competence is not restricted to humans, but has been found in many vertebrates [7]. In their landmark paper, Folstad and Karter developed the idea of hormones driving sexual dimorphism in vertebrates and applied this to Hamilton and Zuk [8] idea that sexually selected ornament traits are dependent on health and vigor and therefore provide honest signals of genetic resistance.
Folstad and Karter's [7] 'immune competence handicap hypothesis' (ICHH) assumes that testosterone suppress immune function. In a nutshell, only males that are highly immune competent can handle the high testosterone titers that are needed to fully express their ornaments. This would result in a strong correlation between ornaments and immune competence (as an indicator of good genes) and hence male ornaments would be honest traits. This elegant concept provides an explanation for how parasite-mediated sexual selection by Hamilton and Zuk could work [7].

The assumption that testosterone is immune suppressive is debatable. While a great number of studies show a correlation between immunity and testosterone levels [9], the experimental evidence is scant. A recent meta-analysis investigating the effects of testosterone on behavior and immunity did not find consistent support for the assumption that testosterone suppresses immunity [10]. Lastly, many species of insect display female-biased sexual dimorphism in immunity [11], yet insects are devoid of sex-specific hormones. Given that many of these species also show a positive correlation between ornament traits and immunity [12], this calls into question the necessity of invoking an "immune competence handicap" for the expression of ornaments.

\section{Possible Hypothesis behind Sexual Dimorphism}

The physiological basis for the sexual dimorphism in immune function is not well understood. Sex differences in morphology, physiology and behavior are usually mediated by sex steroid hormones [13]. Hormones may alter immunologic factors and responses, including antigen expression and presentation, and cytokine production, as well as the expression of apoptotic factors and cell death [14]. The modulatory actions of sex steroid hormones may be 
directly mediated through receptors on immune cells. In mice, the presence of estrogen receptors on various immune cells has been demonstrated, as well as the presence of androgen receptors on $\mathrm{T}$ and $\mathrm{B}$ cells [15]. These sex differences have been attributed in part to the modulatory actions of sex steroid hormones directly on immune cells [15-17]. Gonadal hormones may also influence immunological factors and responses via interactions with antigen expression and presentation, cytokine production, and the induction of apoptotic factors [14, 18, 19]. Importantly, social and environmental factors [19] may significantly modulate both gonadal hormone release and hormonal influences on immune responses. Sex steroid hormones also influence the immune response in part via the thymus in rodents and the bursa of Fabricius in birds through specific androgen and estrogen binding sites [17]. Early work investigating the effects of sex hormones in vitro on isolated leukocytes revealed no correlation between sex steroid concentrations and immune regulation [20]. Exogenous estradiol, however, stimulates adhesion molecules and their receptors on immune cells and accessory cells [21]. Estradiol also has immune enhancing effects on antibody production in vivo, whereas testosterone has immunosuppressive effects on $\mathrm{B}$ and $\mathrm{T}$ cell differentiation, as well as macrophage activation in rats and mice [22]. In birds, exogenous testosterone implants depress antibody production and delayed-type hypersensitivity to an antigen challenges [23]. Although estradiol treatment has immune enhancing effects on humoral immunity, both cellmediated immunity and natural killer cell activity are depressed following estradiol treatment in rats and mice [24-26]. Immune function varies according to reproductive status as well. Male deer often have higher parasite load during the breeding season concomitant with high testosterone concentrations and exaggerated secondary sexual characteristics such as large antlers [27].

Sexual dimorphism in human immune function arises during childhood, but it is not clear whether the molecular and cellular mechanisms involved are the same as those involved in the sexual differentiation of the brain. In all mammals that have been studied, a female phenotype unfolds during development in the absence of the androgenic products of the testes. During embryogenesis, the testes develop only after transcription of a gene on the $\mathrm{Y}$ chromosome, which encodes the testes determining factor. Early androgen secretions by the testes act to masculine and defeminize the circuitry of the male brain. This organizational action of androgen sets the stage for the post-pubertal activated effect of sex steroids. A number of genetic anomalies, e.g., testicular feminization syndrome (Tfm) or environmental perturbations, e.g., maternal stressors, drugs, etc., are known to interrupt the actions of androgens and consequently the process of masculinization of the brain. Sexual dimorphism in the adult rodent or primate brain is evident even in the absence of sex steroids [28]. For example, male rats castrated in adulthood are more sensitive to exogenous androgen as measured by behavioral tests and are less likely to respond with lordosis to estrogen treatment than gonadectomized females. This dimorphism can be abolished if castration occurs prior to the perinatal androgen surge that organizes the CNS, or if females are treated with sex steroids early in development. Therefore, the exposure to secretions from the testes early in life has a permanent effect on the CNS. What evidence is there that a similar organizational action of androgen occurs in the tissues and cells of the developing immune system?

\section{Dimorphism in Humoral and Cellular Immunity}

A number of studies in various species, including humans, describe dimorphism in both humoral and cellular responses. Women have higher plasma IgM levels than men [29]; this difference becomes most significant at the time of puberty and is demonstrable in both African-American and white populations [30]. Levels of serum IgG have been found to be higher in black American women than in black American men, but no such gender difference in IgG levels are observed in the white population [30]. In animal studies, females show more vigorous antibody responses to exogenous antigens [31]. Thymocytes and lymphocytes from normal female mice respond more vigorously to exogenous and allogeneic antigens than do cells from male mice. Parallel studies of $\mathrm{T}$ cell function in humans are lacking; however, quantitative differences in relative numbers of functional $\mathrm{T}$ cells have been related to gender $[32,33]$. Higher CD4:CD8 ratios are generally seen in females and hypogonadal males [34] due to relatively lower numbers of circulating CD8 $\mathrm{T}$ cells. Specifically cell-mediated immune responses differ between males and females. Tcells, in particular helper T-cells (Th cells), are functionally and phenotypically heterogeneous and can be differentiated based on the cytokines they release. Reliance on subsets of Th cells (i.e. Th1 or Th2 cells) to overcome infection differs between males and females with females exhibiting higher Th2 responses (i.e. higher interleukin (IL-4, IL-5, IL-6, and IL-10 production) than males [35]. Female rodents also have higher mitogen stimulated lymphocyte proliferation and increased immunological intolerance to foreign substances than males [36]. The thymus in female mice is larger, and castration of young males leads to an increase in weight of the thymus and secondary immune organs [37] and to an expansion of bone-marrow B cells [38]. In the hamster, sexual dimorphism in the primary and secondary antibody response arises around puberty and is correlated with larger relative spleen weights in females [39]. Sexual dimorphism can be demonstrated in many aspects of immune function. For example, in the mouse, complement is particularly interesting, because there is not only a quantitative, but also a qualitative difference. Electrophoresis of plasma from the male reveals molecular forms of complement $\mathrm{C} 5$ 
and BF which are absent in females. In vitro studies of Fisher-344 rat macrophages also show that cells derived from females produce larger amounts of prostaglandin $\mathrm{E}$ and thromboxane B2 than those from males [40] Women develop higher titers of antibodies in response to immunization, reject transplanted tissues more quickly, are more susceptible to allergies and live longer than men. They also experience elevated frequencies of many autoimmune diseases with systemic lupus erythematosus SLE and Sjogren's syndrome nine times more common in females. Autoimmune nephropathies and Type 1 diabetes, on the other hand, are slightly more common in males. Interestingly, SLE can occur prepubertally but it is not clear if the sex ratio favors girls at this stage; however, some parameters of immune function are sexually dimorphic even in childhood. For example, Butterworth et al., [29] showed that differences in immunoglobulin$M$ levels begin in mid-childhood with girls having higher levels. A whole host of sex differences such as these has prompted extensive research on sex-steroid regulation of immune response and autoimmunity in animal models. The earlier studies have been well reviewed by Schuurs and Verheul [41].

\section{Neuroendocrine Regulation of Immune Function}

The immune system is affected by many external and internal factors such as our hormone system. Recent studies are only now showing us how complicated the relationship is between our immune system and hormone system. Good example is a recent study showing that we respond to infection with complex bidirectional communication between our immune system and our neuroendocrine system [42]. Cells of the immune system contain receptors for neuroendocrine hormones, that is, they receive messages. Immune system then sends out the troops. It also forms amino acid chains called peptides. These peptides are similar to the hormones produced by neuroendocrine system. They appear to function as immune regulators as well as information carriers from the immune system back to the neuroendocrine system. Another recent study showed the importance of this communication. This study investigated the role of the pineal gland and its principal hormone, melatonin on the immune system, through its control of the release of cytokines [43]. The study was carried out on 31 cancer patients with advanced solid tumors who had failed to respond to chemotherapy and radiotherapy. The patients received melatonin for three months. Thirty-nine percent of patients achieved disease stabilization with no further growth of either the primary or secondary tumors. The researchers concluded that the pineal gland and melatonin in particular, modulate immune function in cancer patients by activating the cytokine system which then exerts growth-inhibitory properties over a wide range of tumor cell types.
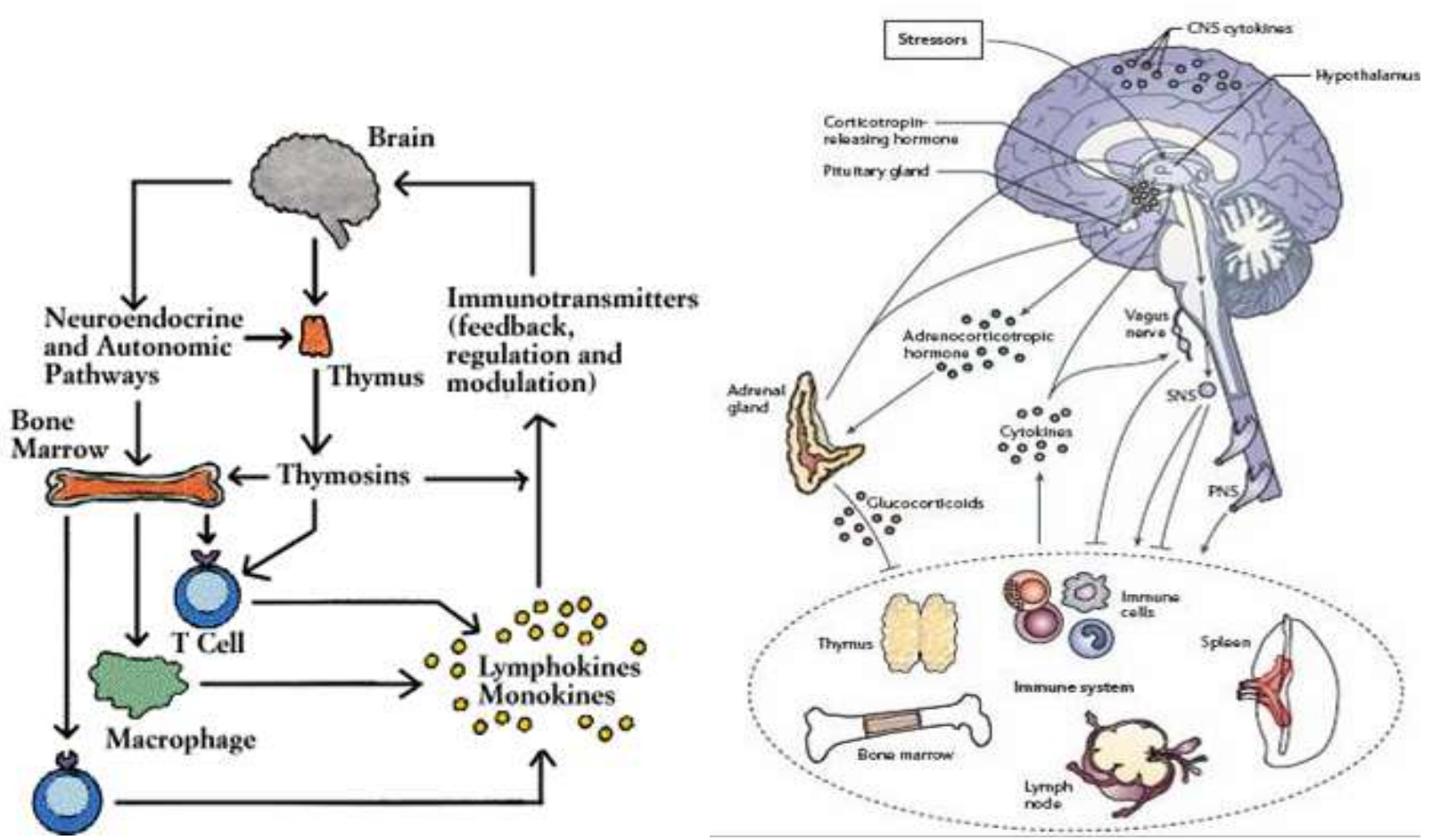

Fig-2: (Photo Courtesy www.google.co.in) [44] 
Table-1: Neuroendocrine-immune interactions

\begin{tabular}{|c|c|}
\hline Hormone & Cytokine/ Immune Function \\
\hline$\alpha$-endorphin & Inhibits Ig production \\
\hline$\alpha$-MSH & Suppresses DTH and inhibits IL-1 and IL-2 production via inhibition of NF- $\kappa \mathrm{B}$ \\
\hline Acetylcholine & $\begin{array}{l}\text { Stimulates T and NK cells and increases IFN- } \gamma \text { production ACTH Inhibits IFN- } \gamma \text { production and Ig } \\
\text { production and blocks macrophage activation by IFN- } \gamma\end{array}$ \\
\hline Adrenaline & Inhibits IL-1 and IL-2 production \\
\hline Angiotensin 2 & Enhances IFN- $\gamma$ production \\
\hline$\beta$-endorphin & Enhances IFN- $\gamma$ production and NK-cell mediated cytotoxicity, Inhibits T-cell proliferation \\
\hline cAMP & Enhances IL-4 and IL-5 production, Inhibits IL-2 production \\
\hline $\begin{array}{l}\text { Calcitonin-gene- } \\
\text { related peptide }\end{array}$ & Increases T-cell adhesion and stimulates IL-2, IL-4 and IFN- $\gamma$ production \\
\hline \multirow[t]{2}{*}{ Catecholamines } & $\begin{array}{l}\text { Enhance Ig production. Decrease the number of T and NK cells in the peripheral circulation and } \\
\text { inhibit NK cells }\end{array}$ \\
\hline & $\begin{array}{l}\text { Inhibits IFN- } \gamma \text {, IL- } 2 \text {, IL- } 6 \text { and TNF- } \alpha \text { Enhances IL- } 4 \text { and TGF- } \alpha \text { production, Enhances immune } \\
\text { cell expression of IL- } 1, \text { IL- } 2, \text { IL- } 6 \text { and IFN- } \gamma \text { receptors }\end{array}$ \\
\hline Cortisol & Activates macrophages, Inhibits IL-1 and IL-6 production \\
\hline DHEAS & Enhances IFN- $\gamma$ production and T-cell proliferation \\
\hline Growth hormone & Activates macrophages and enhances $\mathrm{H} 2 \mathrm{O} 2$ production \\
\hline $\begin{array}{l}\text { Gonadotropin- } \\
\text { releasing hormone }\end{array}$ & Increases IL-2R expression, $\mathrm{T}$ - and B-cell proliferation and serum Ig \\
\hline Histamine & Inhibits IL-12, TNF- $\alpha$ and IFN- $\gamma$ and enhances IL-10 production \\
\hline Inhibin & Inhibits IFN- $\gamma$ production \\
\hline IGF1 and IGF2 & Enhance PBMC proliferation \\
\hline LH & Enhances IL-2 stimulated T-cell proliferation \\
\hline $\begin{array}{l}\text { Macrophage } \\
\text { inhibitory factor }\end{array}$ & Blocks glucocorticoid inhibition of T-cell proliferation and cytokine production \\
\hline Melatonin & Enhances IL-1, IL-2, IL-6 and IFN- $\square \gamma$ production \\
\hline Met-enkephalin & Enhances antigen-specific proliferation \\
\hline Nerve growth factor & Enhances B-cell proliferation, IL-6 production, IL-2 receptor expression and Ig-G4 synthesis \\
\hline Neuropeptide Y & Increases T-cell adhesion and stimulates IL-2, IL-4 and IFN- $\gamma$ \\
\hline Oestrogen & Enhances T-cell proliferation and activity IFN- $\gamma$ gene promoter \\
\hline Oxytocin & Enhances IFN- $\gamma$ production \\
\hline PGE2 & Inhibits IL-2 production \\
\hline Progesterone & Enhances IL-4 production and CD30 expression \\
\hline Prolactin & Enhances T-cell proliferation, IFN- $\gamma$, IL-2 receptor expression and macrophage function \\
\hline Serotonin & Inhibits T-cell proliferation and IFN- $\gamma$ induced HLA class II expression, Enhances NK cytotoxicity \\
\hline Somatostatin & Inhibits T-cell proliferation and IFN- $\gamma$ production \\
\hline Substance P & Enhances T-cell proliferation and IL-1, IL-6, TNF- $\alpha$ and IFN- $\gamma$ production and macrophage action \\
\hline Testosterone & Enhances IL-10 production \\
\hline TSH & Enhances IL-2, GM-CSF and Ig production \\
\hline Thyroxine & Activates T cells \\
\hline Vitamin D3 & Inhibits IL-2 and IFN- $\gamma$, Enhances IL-4 production \\
\hline Vasopressin & Enhances IFN- $\gamma$ production \\
\hline VIP & Inhibits T-cell proliferation and IL-12 Enhances IL-5 and cAMP production \\
\hline
\end{tabular}

Source: Nikolai Petrovsky, Towards a unified model of neuroendocrine-immune interaction, Immunology and Cell Biology (2001) 79, 350-357 [45].

ACTH- adrenocorticotrophic hormone; CRHcorticotrophin-releasing hormone; DHEASdehydroepiandrosterone sulfate; DTH-delayed type hypersensitivity; IGF- insulin-like growth factor; LHluteinizing hormone; $\mathrm{MSH}$ - melanocyte-stimulating

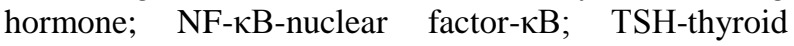
stimulating hormone; VIP- Vasoactive Intestinal Polypeptide.

\section{Role of Different Hormones in Sex Dependent Immune Response}

Darwin [46] noted that frequently males are short-lived than female co specifics; this observation is particularly true among polygynous species [47]. Although there is evidence that differential environmental and social interactions can account for some of the sex differences in mortality, it is clear that, males and females differ in immune function. For example, when male and female mice are maintained in germ-free environments, the sex difference in longevity vanishes. Sex differences have been reported for several immune indices [18, 25, 36, 41]. In general, sexually mature females seem to have higher immune activity than male conspecifics. For example, females of many species, including humans, have higher circulating immunoglobulin levels than male co specifics [47, 48]. 
Females also mount higher antibody responses after an immunological challenge than males [41]. Macrophages from adult female rats produce more interleukin-1 (IL1) than pre-pubertal females or adult males [49]; ovariectomy reduces macrophage IL-1 production in female rats and estrogen replacement therapy reverses this reduction [50]. Cell-mediated immunity has been reported to be both lower [51] and higher [52, 53] in female mammals as compared to males. However, virtually all studies indicate that females exhibit higher resistance to tumors and parasites than males [18, 54]. Many sex differences in immune function appear to be organized early in development and are activated at the time of puberty [18], although some appear only to be activated by peri-pubertal increases in sex steroid levels [41].

Females are also more resistant than males many diseases [18, 36, 41]. Among humans, for example, females are less likely than males to contract bacterial meningitis, bacterial septicemia, dysentery, gonorrhea, meningitis, pneumonia, Legionnaire's disease, hepatitis B, rabies, syphilis, tetanus, typhoid, and yellow fever [36]. The disadvantages for such superior immunological function and resistance to disease among females include enhanced proclivity for developing autoimmune disease [18, 36, 41]. Women are more likely than men to suffer from systemic lupus erythematosus (9:1), Sjogren's syndrome (10:1), rheumatoid arthritis (3:1 to 7:1), multiple sclerosis (2:I), Graves disease, thyroiditis, and certain forms of diabetes [18, 36, 41]. Animal models for many human autoimmune diseases exist, and hormonal manipulations in these animal models have indicated the involvement of sex steroid hormones in their expression [55]. Furthermore, natural hormonal changes in humans (e.g., pregnancy, menopause) have an effect on immune function and some diseases. Generally, estrogens are immune stimulatory, androgens are immune compromising, and progestins can be either stimulatory or suppressive of immune function.

\section{Role of Gonadal Steroids in Immune Modulation}

Steroidogenesis is the biological process by which steroids are generated from cholesterol and transformed into other steroids. Both clinical and experimental evidence support the hypothesis that gonadal steroids regulate immune function. This conclusion is based on the following observations: (i) a sexual dimorphism exists in the immune response; (ii) the immune response is altered by gonadectomy and sex steroid hormone replacement; (iii) the immune response is altered during pregnancy when the amount of sex steroid hormone is increased; and (iv) the organs responsible for the immune response contain specific receptors for gonadal steroids.

\section{Role of Androgen}

Testosterone generally suppresses immune function. Castration of adult male rodent's results in increased immunoglobulin levels, increased humoral and cell-mediated immunity, and increased lymphatic organ size, including thymic, splenic, and lymph nodal masses [41]. Castration of male rodents leads to similar immune responses, but they are not equivalent to those females; this suggests that some of the sex difference in immune function is organized prior to puberty. Treatment of adult castrated males with physiological doses of testosterone restore (i.e. depress) immune function to pre-castration levels [18, 41].

Testosterone replacement therapy of castrated or intact male rats and mice significantly suppressed humoral and cell-mediated immunity, as well as thymic mass $[36,41]$. Androgen receptors have been identified in thymic tissues, particularly in the epithelial, lymphatic portion of the thymus [25, 56]. Androgenic effects on lymphocytes may be in direct or through aromatization of androgens to estrogens, because no androgen receptors have been found on circulating lymphocytes [25]. It is apparent that the immune and reproductive systems are intimately interconnected and that androgens are important components of these interactions. Indeed, the immune system can be modulated by androgens in some cases; conversely, activation of the immune system, particularly the innate arm, is associated with suppression of the reproductive neuroendocrine axis [57]. Further, in domestic fowl, birds selected for strong antibody responses have smaller combs, sexually selected traits that are testosterone dependent and lower testosterone titers [58]. Conversely, chickens infected with an intestinal parasite exhibited similar concentrations of testosterone and similar-sized combs as uninfected birds [59]. As evidenced by these studies, trade-offs between reproduction and immune function may be mediated directly via communication between the reproductive and immune systems in certain contexts [60, 61], although these interactions tend to be complex. The apparent immunosuppressive effects of androgens may sometimes be due to glucocorticoids $[62,63]$, at least in certain experimental contexts. For example, captive dark-eyed juncos (Junco hyemalis) implanted with testosterone had reduced PHA responses when compared with those without implants. This effect could not be attributed directly to testosterone, as birds with implants also had higher circulating Corticosterone [64]. Similarly, house sparrows implanted with testosterone had decreased antibody response but increased corticosterone concentrations.

\section{Effects of Androgens on Cellular and Humoral Immunity}

Several studies in both animals and humans have been performed in an attempt to understand the influence of sex steroids on the immune system. Androgens exert considerable effects on the size and composition of the thymus. Removal of androgens by castration resulted in thymic enlargement even in old rats and androgen replacement reversed this effect [65]. 
In one study, testosterone replacement in castrated male mice caused thymic regression, with a shift towards expression of mature thymocytes and predominance of the suppressor/cytotoxic CD4- CD8+ phenotype over the helper CD4+ CD8- phenotype [66]. Mechanisms of androgen-induced thymus involution are incompletely understood, but decreased cell proliferation; changes in cell trafficking and increased apoptosis are some of the possible mechanisms involved. The role of apoptosis was suggested by one study from Olsen et al., [67], in which a single dose of testosterone markedly decreased thymic size within hours in castrated mice; increased DNA fragmentation was shown, suggesting thymocyte apoptosis. Recently, it has been shown that testosterone specifically targets double positive (CD8+ CD4+) thymocytes for apoptosis via upgrading tumor necrosis factor- $\alpha$ production [68]. On the other hand, documentation of classical AR expression in peripheral $\mathrm{T}$ cells has not been reported but the net effect of androgen action (direct or indirect) seems to be an enhanced suppressor effect [15]. The number of pre-B cells in bone marrow and mature peripheral B cells increases in male mice after castration [69]. It has been reported that treatment of mice with dihydrotestosterone (a non-aromatized androgen) suppressed the expansion of lineage precursors (IL-7 responsive precursors) when added to short-term co-cultures of lymphocytes and stromal cells [70, 71]. There are conflicting data concerning the effects of castration and androgens on peripheral B cells. CD5+ cell subsets have been implicated as an important source of auto-antibodies. An early study showed that this B cell subset did not expand in spleens of castrated male mice, whereas estrogen treatment in female mice augmented the CD5+ cell subset activity [55], suggesting the greater importance of estrogen (rather than absence of androgen) in activation of CD5+ cell subsets. In a recent study, castration in male mice was shown to selectively increase splenic cellularity and the number of peripheral blood lymphocytes due to newly emigrated immature B cells. It was concluded that the numbers of $\mathrm{B}$ cells in male mice were controlled by physiological levels of androgen [72].

\section{Estrogen}

In contrast to the pattern of androgen receptor localization, estrogen receptors have been localized in the cytosol of circulating lymphocytes [16, 18, 73], CD8+ cells [74, 75], and thymic cells [73, 76]. Physiological treatment of estrogen, or the estrogen receptor antagonists, tamoxifen and $\mathrm{FC} 1157 \mathrm{a}$, enhances pokeweed mitogen induced immunoglobulin synthesis of B-lymphocytes [77].

Treatment of intact male or gonadectomized male or female mice and rats with physiological or supra-physiological doses of estrogens increases antibody responses to a variety of T-dependent and $\mathrm{T}$ independent antigens [51, 78]. Cyclic exposures to pharmacological doses of estrogens are more effective in boosting antibody formation than chronic estrogen exposure [41]. Pharmacological doses of estrogens also suppress cell-mediated immunity [18, 79]. Tamoxifen inhibits the effects of estrogens on antibody formation and cell-mediated immunity [80, 81]. Taken together, the effects of physiological doses of estrogen appear to enhance immune function.

\section{Effects of estrogens on cellular and humoral immunity}

Estrogen treatment has been shown to cause significant thymic atrophy and to decrease the number of thymocytes in mice [82]. In a study with ovariectomized female rats, ovariectomy increased thymic size and had a profound effect on the thymocyte profile, leading to an increase in the CD4+CD8+ immature cells, with a decrease in the relative proportion of the mature cells, which was opposed by treatment with physiological doses of estradiol-17 $\beta$ [83]. Estrogen also stimulates CD4+CD8- cells and can activate an extra-thymic pathway of auto-reactive $\mathrm{T}$ cell differentiation in the liver [82, 84]. Several studies have established that estrogen is a potent inhibitor of stromal cell-dependent B cell lymphopoiesis in vitro. In bone marrow, all the precursors beyond the early pro-B cell stage are affected by estrogen [85, 86]. In a recent study, the same authors observed a dramatic reduction in $\mathrm{B}$ cell lineage differentiation and expansion when estrogen was added to stromal-free cultures, suggesting a direct effect of estrogen on early pro-B cells [87]. Estrogen also affects peripheral B cells and humoral immunity. Estrogen treatment in normal male or female mice increased the number of antibody-producing cells and the levels of circulating auto-antibodies against double-stranded DNA (dsDNA) without any increase in $B$ cell count [88]. In another study, using human peripheral blood mononuclear cells, estrogen treatment was showed to enhance immunoglobulin production, partially by increasing IL-10 production [89]. In summary, androgens and estrogen are potent immune modulators. Sex steroids act as negative regulators in both the thymus and bone marrow, but androgens and estrogen tend to affect different subsets of immune cells. In general, androgens seem to inhibit immune activity, while estrogen seems to have a more powerful effect on immune cells and to stimulate immune activity.

\section{Role of stress hormone (glucocorticoid) in immune modulation}

Glucocorticoids are the end product, primary effectors and principal negative regulators of an important neuroendocrine axis (hypothalamuspituitary-adrenal (HPA) axis). Originally described for their role in energy mobilization, glucocorticoids are now recognized as powerful mediators of many physiological processes including reproduction and immune activity. Unlike other hormones, glucocorticoids tend to suppress both reproduction and immune function. The effects of glucocorticoids on 
immune function and susceptibility to infection are most well understood in mammalian species. High circulating Corticosterone concentrations suppress innate (i.e. natural killer cell activity), cell-mediated (i.e. cytokine production) and humoral (i.e. antibody production) immune responses in laboratory rats and mice [90, 91]. Furthermore, adrenalectomy increases lymphoid tissue mass and B-cell activity in mice [92]. Laboratory studies in rodents have demonstrated that basal corticosterone concentrations are higher among females and rise more rapidly in females than males following exposure to stressors [93, 94]. Males and females often differ in the types of stressors they encounter, especially during the breeding season [95, 96]. Thus, exposure to stressors may influence sex differences in immune function and subsequent resistance to infection [27]. This observation has led to the principles that elevated glucocorticoids promote physiological and behavioral responses that (i) favor immediate survival at the expense of other processes (i.e. the emergency life history stage hypothesis [97] and (ii) maintain homeostasis in the face of environmental changes (i.e. allostasis; [98]. Interaction between glucocorticoids and the immune system is complex and bidirectional. Stressor- induced elevated glucocorticoid concentrations can modulate immune activity; however, activation of the immune system can also drive the production of glucocorticoids [57, 99]. Because glucocorticoids tend to suppress inflammation but be induced by pro-inflammatory stimuli, they have been conceptualized as 'brakes' on the immune system, having evolved to prevent runaway inflammation and promote fine-tuning of the immune response [100]. A wealth of information demonstrates how glucocorticoids suppress immune function [99], which led to the conjecture that glucocorticoids are largely responsible for decrements in immune activity in freeliving animals in winter [101]. Now there is compelling evidence that in certain contexts glucocorticoids can enhance aspects of immune function. In many cases, immune suppression may be immune redistribution in disguise [102]. From an adaptive perspective, one might predict that animals would enhance immune function in parts of the body at times when injury is probable, such as during a territorial dispute or failed predation event. Recent data in mice and rats support part of this prediction; in response to acute stressors, circulating leucocytes do not die, but instead they leave the bloodstream and move into peripheral tissues (skin, gut and lymph nodes). In the absence of injury or infection, these cells return to the general circulation quickly [103]. One of the best examples of these stress-induced immune redistributions comes from work on delayedtype hypersensitivity (DTH). The DTH response is characterized by T-cell mediated trafficking of immune cells into the skin [104]. These stress-induced alterations in the DTH response were directly mediated by corticosterone. Photoperiod affects the character of these stress induced immunological redistributions, suggesting that these hormones probably influence seasonal changes in immune activity in wild animals. Siberian hamsters acutely stressed prior to immune challenge had elevated DTH responses, and this response was significantly augmented in short versus long day animals [105]. This enhancement in skin immune function was associated with an enhanced glucocorticoid response and expedited movement of leucocytes out of the blood during restraint stress in short versus long day-housed hamsters [105]. As with photoperiod, latitude of origin can also influence corticosteroid effects on the immune system. Tropicaldwelling, but not temperate, house sparrows failed to show immune suppression in response to chronically elevated corticosterone [106].

\section{Role of Metabolic Hormone (Thyroxin) in Immune Modulation}

Thyroid hormones are basically known regulate Basal Metabolic Rate (BMR) of the body. But the immune modulatory role of this hormone is least known and in need to be elucidated. However, reports suggest that it is helpful in differentiation, growth, metamorphosis, metabolism [107] and play a prominent and critical role in regulation of reproduction [108]. Some previous reports suggest that thyroxin (T4) caused thymus enlargement and increase in umber of peripheral lymphocyte [109]. However, thyroidectomy resulted in hypoplasia of lymphoid organs [110] as thyroid hormones are reported to increase the nucleated cells in spleen and thus improving the immune status of an immune compromised animal to the threshold level [111]. Some of the reports are contradictory to the previous citations where Weetman et al., [112] reported that under in vivo and in vitro conditions thyroxin has no role in immune modulation. Some other report of Gupta and Thapliyal [113] suggests that thyroxin in immune inhibitor in nature. But most of the reports are mainly from birds but not from mammals. Some partial report [114] suggests that thyroid hormone functions may be modulated by melatonin and it can also affect the lymphoid organ function by modulating PinealThyroid Axis [108]. But, the exact role of thyroid hormone function in modulation of immunity is till date controversial, partial and in need to be explored out.

\section{Neuroendocrine Immune Cross-Talk}

A good example of neuroendocrine immune cross-talk is the role of prolactin in regulation $\mathrm{T}$-cell cytokine production. Prolactin shares target transcription factors including interferon regulatory factor-1 (IRF-1) with IL-2 [115]. Prolactin receptors are expressed on $\mathrm{T}$ and NK cells and prolactin increases IL2 -stimulated NK-cell IFN- $\gamma$ production [115]. This is an example of an increasingly recognized phenomena whereby simultaneous signaling via hormone and cytokine receptors on $\mathrm{T}$ cells results in downstream interaction of receptor signaling pathways and results in $\mathrm{T}$-cell behavior that may not be predicted on the basis of signaling through individual receptors. $\mathrm{T}$ cells express over 20 neuroendocrine receptors and at least as 
many cytokine receptors and thus the level of complexity of intracellular cross-talk must be immense. The diversity of T-cell behavior under different conditions is likely, therefore, to have its origins in this receptor cross-talk involving neuroendocrine and cytokine receptors. Thus, reductionist experiments examining the role of individual factors in T-cell subset differentiation may be less important than examination of the overall cytokine and hormonal milieu in vivo at the time of $\mathrm{T}$-cell activation in understanding $\mathrm{T}$-cell subset differentiation.

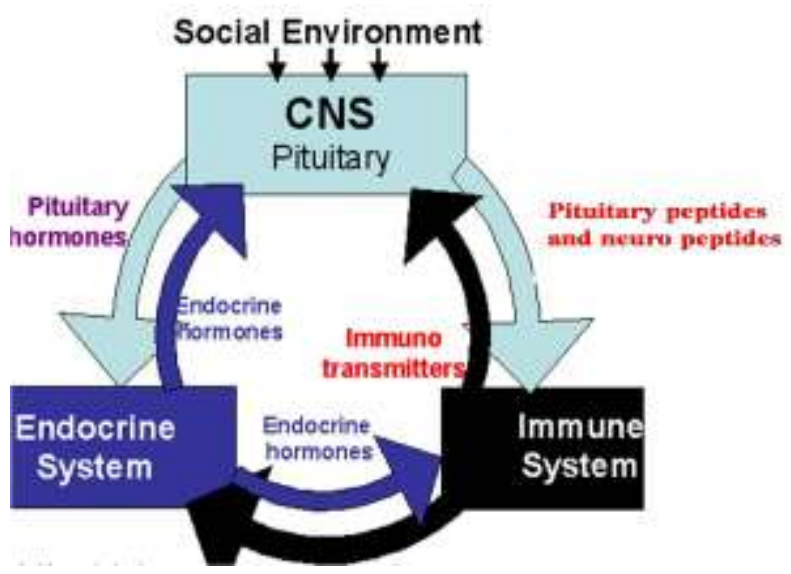

Fig-3: (Photo courtesy www.google.co.in) [41]

\section{Cytokine regulation of neuroendocrine function:}

In keeping with the bidirectional nature of the neuro-endocrine and immune pathways, cytokines also influence neuroendocrine function. This was highlighted by the early finding that corticosterone levels are increased several fold during the primary immune response of rats to sheep red blood cells. Immune influences on neuroendocrine function are now known to be principally mediated by cytokines, receptors for which are widely expressed throughout the neuroendocrine system.

The first cytokines shown to have neuroendocrine effects were the interferons, administration of which increases steroidogenesis. Subsequently, IL-1, IL-2 or IL-6, IFN- $\gamma$, IFN- $\beta$, leukaemia inhibitory factor (LIF) and TNF- $\alpha$ have been shown to elevate plasma ACTH and glucocorticoid levels in both laboratory animals and humans [116118]. Cytokines also regulate the secretion of non-HPA axis hormones. For example, IFN- $\gamma$, granulocyte colony stimulating factor (G-CSF) and GM-CSF stimulate melatonin release by the pineal gland [119]. Potentially, this constitutes yet another positive feedback loop because melatonin itself enhances IFN- $\gamma$ production [120]. Interferon- $\gamma$ up regulates glucocorticoid receptor expression by macrophages, suggesting that the action of glucocorticoids on immune cells may be enhanced at times of immune system activation [121].

Some cytokines may even cross-react with neuroendocrine receptors. For example, IL-2 has analgesic effects in both the central and peripheral nervous systems and this may be mediated through interaction of the analgesic domain of IL-2 with the opioid receptor.

\section{Expression of hormone by Immune cells}

Lymphocytes express receptors for a wide variety of hormones, including cortisol, prolactin, GH and melatonin. Immune cells are also capable themselves of expressing many hormones. Over 20 different neuroendocrine hormones and/or mRNA for hormones including ACTH, thyroid stimulating hormone (TSH), GH, prolactin and CRH are expressed by lymphocytes and/or monocytes [122]. For example, human PBMC express gonadotropin - releasing hormone $(\mathrm{GnRH}), \mathrm{GnRH}$ receptor and IL-2 receptor gamma-chain mRNA that are regulated by $\mathrm{GnRH}$ in vitro [123]. Thymus expressed glucocorticoid may even have a role in the regulation of antigen-specific T-cell development [124].

\section{CONCLUSION}

From the brief review we may conclude that there are gender dependent variations of hormonal regulation of immunity irrespective of the fact that the hormone is immune-enhancing, immune-suppressive or immune-neutral. However in depth molecular studies are warranted to get a holistic view.

\section{REFERENCES}

1. Metchnikoff E. The Evolutionary Biology Papers of Elie Metchnikoff, Eds Williamson, GH and Tauber, DIAI, Kluwer Academic Publishers, Dordrecht, 2000.

2. Delves PJ, Roitt IM. The immune system: First of two parts. N Eng J Med 2000; 343: 37- 49.

3. http://www. nature.com

4. Janeway CA Jr, Medzhitov R. Innate immune recognition. Ann Rev Immunol 2002; 20: 197-216.

5. Boyle P, Ferlay J. Cancer incidence and mortality in Europe. Ann Oncol 2005; 16: 481-488.

6. Whitacre CC. Sex differences in autoimmune disease. Nat Immunol 2001; 2: 777-780.

7. Folstad I, Karter AJ. Parasite, bright males and immune competence handicap. Am Nat 1992; 139: 603-622.

8. Hamilton WD, Zuk M. Heritable true fitness and bright birds: a role for parasites? Science 1982; 218: 384-387.

9. Muehlenbein MP, Bribiescas RG. Testosteronemediated immune functions and male life histories. Am J Hum Biol 2005; 17: 527-558.

10. Roberts SC, Havlicek J, Flegr J, Hruskova M, Little AC, Jones BC, Perrett DI, Petrie M. Female facial attractiveness increases during the fertile phase of the menstrual cycle. Proc R Soc London B (Suppl.) 2004; 271: S270-S272.

11. Kurtz J, Wiesner A, Gotz P, Sauer, KP. Gender differences and individual variation in the immune system of the scorpionfly Panorpa vulgaris 
(Insecta: Mecoptera). Dev Comp Immunol 2000; 24: 1-12.

12. Ryder JJ, Siva-Jothy MT. Male calling song provides a reliable signal of immune function in a cricket. Proc R Soc Lond Ser B Biol Sci 2000; 267: 1171-1175.

13. Cooke B, Hegstrom CD, Villeneuve LS, Breedlove SM. Sexual differentiation of the vertebrate brain: principles and mechanisms. Front Neuroendocrinol 1998; 19: 323-362.

14. Huber SA, Kupperman, J, Newell MK. Hormonal regulation of $\mathrm{CD} 4(+) \mathrm{T}$-cell responses in coxsackie virus B3-induced myocarditis in mice. J Virol. 1993; 73: 4689-4695.

15. Olsen NJ, Kovacs WJ. Gonadal steroids and immunity. Endocr Rev 1996; 173: 69-84.

16. Grossman CJ, Roselle GA, Mendenhall CL. Sex steroid regulation of autoimmunity. The J Steroid Biochem Mol Biol 1991; 40: 649-659.

17. Gaillard RC, Spinedi E. Sex and stress-steroids interactions and the immune system: evidence for a neuroendocrine-immunological sexual dimorphism. Domest Anim Endocrinol 1998; 15: 345-352.

18. Grossman CJ. Interactions between the gonadal steroids and the immune system. Science 1985; 227: 257-261.

19. Klein SL. Hormones and mating system affect sex and species differences in immune function among vertebrates. Behav Proc 2000; 51: 149-166.

20. Schiff I, Regestein Q, Tulchinsky D, Ryan KJ. Effects of estrogens on sleep and psychological state of hypogonadal women. Jama 1979; 242: 2405-2419.

21. Cid MC, Hynda K, Kleinman T, Derrick S, Grant H, Schnaper W, Fauci AS, Hoffman GS. Estradiol Enhances Leukocyte Binding to Tumor Necrosis Factor (TNF)-stimulated Endothelial Cells via an Increase in TNF-induced Adhesion Molecules ESelectin, Intercellular Adhesion Molecule Type 1, and Vascular Cell Adhesion Molecule Type 1. The J Clin Invest. 1994; 93: 17-25.

22. Savita S, Rai U. Sex steroid hormones modulate the activation of murine peritoneal macrophages: receptor-mediated modulation. Comp Biochem Physiol 1998; 119: C199-C204.

23. Duffy DL, Bentley GE, Drazen DL, Ball GF. Effects of testosterone on cell mediated and humoral immunity in non-breeding adult European starlings. Behav Ecol 2000; 11: 654-662.

24. McCruden AB, Stimson WH. Androgen receptor in the human thymus. Immunol Lett 1984; 8: 49-53.

25. McCruden AB, Stimson WH. Sex hormones and immune function. In Psychoneuroimmunol Ader R, Cohen J. eds, Academic Press, New York , 475493, 1991.

26. Seaman WE, Gindhart TD. Effect of estrogen on natural killer cells. Arthritis Rheum 1979; 22: 1234-1240.
27. Zuk M, McKean KA. Sex differences in parasite infections: patterns and processes. Int $\mathrm{J}$ Parasitol 1996; 26: 1009-1024.

28. Martin CL, Little JK. The relation of gender understanding to children's sex-type preferences and gender stereotypes. Child Dev 1990; 61: 1427 1439.

29. Butterworth MB, McClellan B, Alansmith M. Influence of sex on immunoglobulin levels. Nature 1967; 214: 1224-1225.

30. Lichtman MA, Vaughan, JH, Hames CG. The distribution of serum immunoglobulins, antigamma-G globulins ("rheumatoid factors") and antinuclear antibodies in White and Negro subjects in Evans County, Georgia. Arthritis Rheum 1967; 10: 204-215.

31. Eidinger D, Garrett TJ. Studies of the regulatory effects of the sex hormones on antibody formation and stem cell differentiation. J Exp Med 1972; 136: 1098-1116.

32. Hallgreem HM, Jakola DR, O'leary JJ. Unusual pattern of surface marker expression on peripheral lymphocytes from aged humans suggestive of a population of less differentiated cells. J Immunol 1983; 131: 191-194.

33. Amadori A, Zamarchi R, DeSilvestro G, Forza G, Cavatton G, Danieli GA, Clementi M. ChiecoBianchi L. Genetic control of the CD4/CD8 T cell ratio in humans. Nature Med 1995; 1: 1279-1283.

34. Bizzarro A, Valentini G, Di Martino G, Daponte A, De Bellis A, Lacono G. Influence of testosterone therapy on clinical and immunological features of autoimmune diseases associated with Klinefelter's svndrome. J Clin Endocrinol Metab. 1987; 64: 3236.

35. Bijlsma JWJ, Cutolo M, Masi AT. The neuroendocrine immune basis of rheumatic diseases. Immunol Today 1999; 20: 298.

36. Billingham RE. Immunologic advantages and disadvantages of being a female. In: Clarke DA Croy B. (Eds.) Reprod Immunol Elsevier Science Publishers, New York, 1-9, 1986.

37. Nelson JL, Steinberg, AD. Sex steroids, autoimmunity and autoimmune disease, 93-119 in: Hormone Immunity. Berczi M, Kovacs K. ed. MTP Press, The Hague, Belgium, 1987.

38. Viselli SM, Reese KR, Fan J, Kovacs WJ, Olsen NJ. Androgens alter B cell development in normal male mice. Cell Immunol 1997; 182: 99-104.

39. Blazkovec AA, Orsini MW. Ontogenetic Aspects of Sexual Dimorphism and the Primary Immune Response to Sheep Erythrocytes in Hamsters from Pre puberty through Senescence. Int Arch Allergy Appl Immunol 1976; 50: 55-67.

40. Du JY, Ruan YC, Zuo WL, Yang ZH, Chen MH, Wu ZL, Xiang H, Zhou WL. Cellular mechanisms of carbachol-stimulated $\mathrm{Cl}-$ secretion in rat epididymal epithelium. Biol Reprod 2006; 75: 407 413 
41. Schuurs AHWM, Verheul HAM. Effects of gender and sex steroids on the immune response. J Steroid Biochem 1990; 35: 157-172.

42. Weigent DA, Blalock JE. Associations between the neuroendocrine and immune systems. J Leukoc Biol 1995; 58: 137-150.

43. Neri B, de Leonardis V, Gemelli MT. Melatonin as biological response modifier in cancer patients. Anticancer Res 1998; 18: 1329-1332.

44. http:// www.google.co.in

45. Petrovsky N. Towards a unified model of neuroendocrine-immune interaction. Immunol Cell Biol 2001; 79: 350-357.

46. Darwin CR. The descent of man and selection in relation to sex. London, John Murray, 1, 1ed, 1871.

47. Rhodes K, Markham RL, Maxwell PM, MonkJones ME. Immunoglobulins and the Xchromosome. Br Med J 1969; 3: 439-441.

48. Nelson RJ, Drazen DL. Melatonin mediates seasonal changes in immune function. Ann N Y Acad Sci 2000; 917: 404-415.

49. Hu S, Peterson PK, Chao CC. Cytokine-mediated neuronal apoptosis. Neurochem Int 1997; 30: 427431.

50. Ho AK, Klein DC. Activation of alpha 1adrenoceptors, protein kinase $\mathrm{C}$, or treatment with intracellular free $\mathrm{Ca} 2+$ elevating agents increases pineal phospholipase A2 activity. Evidence that protein kinase $\mathrm{C}$ may participate in $\mathrm{Ca} 2+$ dependent alpha 1-adrenergic stimulation of pineal phospholipase A2 activity. J Biol Chem 1987; 262: 11764-11770.

51. Inman RD. Immunologic sex differences and the female predominance in systemic lupus erythematosus. Arthritis Rheum 1978; 21: 849-852.

52. Comsa J, Leonhardt H, Wekerle H. Hormonal coordination of the immune response. Rev Physiol Biochem Pharmacol 1982; 92: 115-191.

53. Lenarsky C, Weinberg K, Guinan E, Dukes PP, Barak Y, Ortega, J, Siegel S, Williams K, Lazerson $\mathrm{J}$, Weinstein $\mathrm{H}$. Bone marrow transplantation for constitutional pure red cell aplasia. Blood 1988; 71 : 226-229.

54. Ahmed SA, Talal N. Sex hormones and the immune system--Part 2, Animal data. Baillieres Clin Rheumatol 1990; 4: 13-31.

55. Ansar Ahmed S, Penhale WJ, Talal N. Sex hormones, immune responses, and autoimmune diseases Mechanisms of sex hormone action. Am J Pathol 1985; 121: 531-551.

56. Sasson S, Mayer M. Resistance to Androgen in Murine Lymphosarcoma Lines Resistant are Sensitive to Glucocorticoid Hormone. Br J Cancer 1981; 44: 127-130.

57. Turnbull AV, Rivier C. Inhibition of gonadotropininduced testosterone secretion by the intracerebroventricular injection of interleukin-1 beta in the male rat. Endocrinol 1997; 138: 10081013 .
58. Verhulst S, Dieleman SJ, Parmentier HK. A tradeoff between immunocompetence and sexual ornamentation in domestic fowl. Proc Natl Acad Sci, USA 1999; 96: 4478-4481.

59. Zuk M, Johnsen TS. Seasonal changes in the relationship between ornamentation and immune response in red jungle fowl. Proc R Soc Lond B 1998; 265: 1631-1635.

60. Avitsur R, Yirmiya R. Cytokines inhibit sexual behaviour in female rats: I. Synergistic effects of tumour necrosis factor $\alpha$ and interleukin-1. Brain Behav Immun 1999; 13: 14-32.

61. Weil ZM, Hotchkiss AK, Gatien ML, Pieke-Dahl S, Nelson RJ. Melatonin receptor (MT1) knockout mice display depression-like behaviours and deficits in sensorimotor gating. Brain Res Bull 2006; 68: 425-429.

62. Evans SJ, Searcy BT. Moore FL. A subset of kappa opioid ligands bind to the membrane glucocorticoid receptor in an amphibian brain. Endocrinol 2000; 141: 2294-2300.

63. Berger S, Martin LB II, Wikelski M, Romero LM, Kalko EKV, Vitousek MN, Rödl T. Corticosterone suppresses immune activity in territorial Galápagos marine iguanas during reproduction. Horm Behav., 2005; 47: 419-429.

64. Casto JM, Nolan V, Jr Ketterson ED. Steroid hormones and immune function: experimental studies in wild and captive Dark-eyed Juncos (Junco hyemalis). Am Nat 2001; 157: 408-420.

65. Greenstein BD, Fitzpatrick FT, Adcock IM, Kendall MD, Wheeler MJ. Reappearance of the thymus in old rats after orchidectomy: inhibition of regeneration by testosterone. J Endocrinol 1986; 110: 417-422.

66. Olsen NJ, Watson MB, Kovacs WJ. Studies of immunological function in mice with defective androgen action. Distinction between alterations in immune function due to hormonal insensitivity and alterations due to other genetic factors. Immunol 1991; 7:, 52-57.

67. Olsen NJ, Viselli SM, Fan J, Kovacs WJ. Androgens accelerate thymocyte apoptosis. Endocrinol 1998; 139: 748-752.

68. Guevara Patino JA, Marino MW, Ivanov VN, Nikolich-Zugich J. Sex steroids induce apoptosis of CD8+CD4+ double-positive thymocytes via TNFalpha. Eu J Immunol 2000; 30: 2586-2592.

69. Wilson AW, Held, MacDonald HR. Two waves of recombinase gene expression in developing thymocytes. J Exp Med 1994; 179: 1355-1360.

70. Medina KL, Kincade PW. Pregnancy-related steroids are potential negative regulators of $\mathrm{B}$ lymphopoiesis. Proc Nat Acad Sci, USA 1994; 91: 5382-5386.

71. Smithson G, Couse JF, Lubahn DB, Korach KS, Kincade PW. The role of estrogen receptors and androgen receptors in sex steroid regulation of $\mathrm{B}$ lymphopoiesis. J Immunol 1998; 161: 27-34. 
72. Ellis JA, Kemp AS, Ponsonby AL. Geneenvironment interaction in autoimmune disease. Expert Rev Mol Med 2014; 16: e4.

73. Danel L, Souweine G, Monier JC, Saez S. Specific estrogen binding sites in human lymphoid cells and thymic cells. J Steroid Biochem 1983; 18: 559563.

74. Cohen JHM, Danel, L, Cordier G, Saez S, Revillard JP. Sex steroid receptors in peripheral T cells: Absence of androgen receptors and restriction of estrogen receptors to OKT8-positive cells. J Immunol 1983; 131: 2767-2771.

75. Stimson WH. Oestrogen and human $T$ lymphocytes: Presence of specific receptors in the T-suppressor/ cytotoxic subset. Scan J Immunol 1988; 28: 345-350.

76. Weusten JJAM, Blankenstein MA, GmelingMeyling FHJ, Schuurman HJ, Kater L, Thijssen JHH. Presence of oestrogen receptors in human blood mononuclear cells and thymocytes. Acta Endocrinol 1986; 112: 409-414.

77. Paavonen T. Hormonal regulation of immune responses. Ann Med 1994; 26: 255-258.

78. Myers MJ, Peterson BH. Estradiol induced alterations of the immune system I. Enhancement of IgM production. Int J Immunopharmacol 1985; 7: 207-213.

79. Kuhl H, Gross M, Schneide, M, Weber W, Mehlis W, Stengmuller TM, Taubert HD. The effects of sex steroids and hormonal contraceptives upon thymus and spleen on intact female rats. Contraception 1983; 28: 583-597.

80. Urszula K, Helen R, Strausser JP, Bressler AL. Effects of Sex Hormones on Some $\mathrm{T}$ and B Cell Functions, Evidenced by Differential Immune Expression Between Male and Female Mice and Cyclic Pattern of Immune Responsiveness During the Estrous Cycle in Female Mice. Gen Comp Endocrinol 1981; 1: 73-77.

81. Nagy E, Baral E, Berczi I. Immune System, Estrogens and Antiestrogens IHandbook of Experimental Pharmacology. Volume 135, 343$351,1999$.

82. Okuyam R, Abo T, Seki S, Ohteki T, Suguira K, Kusumi A, Kumagai K. Estrogen administration activates extrathymic $\mathrm{T}$ cell differentiation in liver. J Exp Med 1992; 175: 661-669.

83. Leposavic G, Obradovic S, Kosec D, PejcicKarapetrovic B, Vidic-Dankovic B. In vivo modulation of the distribution of thymocyte subsets by female sex steroid hormones. Int Immunopharmacol 2001; 1: 1-12.

84. Screpanti I, Morrono S, Meco D, Santoni A, Gulino A, Paolini R, Crisanti A, Mathieson B, Frati L. Steroid sensitivity of thymocyte subpopulations during intrathymic differentiation, Effects of 170estradiol and dexamethasone on subsets expressing $\mathrm{T}$ cell antigen receptor of IL-2 receptor. J Immunol 1989; 142: 3378 - 3383 .
85. Medina VM, Dawson-Basoa ME, Gintzler AR. 17 beta-estradiol and progesterone positively modulate spinal cord dynorphin: relevance to the analgesia of pregnancy. Neuroendocrinol 1993; 58: 310-315.

86. Smithson G, Medina K, Ponting I, Kincade PW. Estrogen suppresses stromal cell-dependent lymphopoiesis in culture. J Immunol 1995; 155: 3409-3417.

87. Kincade PW, Medina KL, Payne KJ, Rossi MI, Tudor KS, Yamashita Y, Kouro T. Early Blymphocyte precursors and their regulation by sex steroids. Immunol Rev 2000; 175: 128-137.

88. Verthelyi D, Ansar Ahmed S. Characterization of estrogen-induced autoantibodies to cardiolipin in non-autoimmune mice. J Autoimmun 1997; 10: 115-125.

89. Kanda N, Tsuchida T, Tamaki K. Estrogen Enhancement of Anti-Double-Stranded Dna Antibody And Immunoglobulin G Production In Peripheral Blood Mononuclear Cells From Patients with Systemic Lupus Erythematosus. Arth Rheum 1999; 42: 328-337.

90. Bateman A, Singh A, Kral T, Solomon S. The immune-hypotalamic-pituitary-adrenal axis. Endocr Rev 1989; 10: 92-112.

91. Khansari ON, Murgo AJ, Faith RE. Effects of stress on the immune system. Immunol Today 1990; 11: 170-175.

92. Del Rey A, Besedovsky HO, Sorkin E, Da Prada $\mathrm{M}$, Arrenbrecht, S. Immunoregulation mediated by the sympathetic nervous system, II. Cell Immun 1981; 63: 329-333.

93. Kitay JI. Sex differences in adrenal cortical secretion in the rat. Endocrinol 1961; 68: 818 824.

94. deKloet ER, Oitzl, MS, Joe"ls M. Functional implications of braincorticosteroid receptor diversity. Cell Mol Neurobiol 1993; 13: 433- 455.

95. Nelson RJ, Demas GE. Seasonal changes in immune function. Q Rev Biol., 1996;71: 512-548.

96. Demas GE. The energetics of immunity: a neuroendocrine link between energy balance and immune function. Horm Behav 2004; 45:173- 180.

97. Wingfield JC, Maney DL, Breuner CW, Jacobs JD, Lynn S, Ramenofsky M, Richardson RD. Ecological bases of hormone behaviour interactions: the emergency life history stage. Am Zool 1998; 38: 191-206.

98. McEwen BS, Stellar E. Stress and the individual.Mechanisms leadingto disease. Arch Intern Med 1993; 153: 2093-2101.

99. McEwen BS, Biron CA, Brunson KW, Bulloch K, Chambers WH, Dhabhar FS. The role of adrenocorticoids as modulators of immune function in health and disease: neural, endocrine and immune interactions Brain Res Rev 1997; 23: 79133.

100.Sapolsky RM, Romero LM, Munck AU. How do glucocorticoids influence stress responses? Integrating permissive, suppressive, stimulatory, 
and preparative actions. Endocr Rev 2000; 21: 5589.

101.Nelson RJ, Demas GE, Klein, SL, Kriegsfeld LJ. Seasonal Patterns of Stress, Immune Function, and Disease. 1st edn. Cambridge, Cambridge University Press, 2002.

102. Braude S, Tang-Martinez Z, Taylor GT. Stress, testosterone, and the immunoredistribution hypothesis. Behav Ecol 1999; 10: 345-350.

103.Dhabhar FS, McEwen BS. Acute stress enhances while chronic stress suppresses immune function in vivo: A potential role for leukocyte trafficking. Brain Behav Immun 1997; 11: 286306.

104.Dhabhar FS, Miller, AH, McEwen BS, Spencer RL. Effects of stress on immune cell distributiondynamics and hormonal mechanisms. J Immunol 1995; 154: 5511-5527.

105.Bilbo SD, Drazen DL, Quan N, He L, Nelson RJ. Short daylengths attenuate the symptoms of infection in Siberian hamsters. Proc Biol Sci 2002; 269: 447-454.

106. Martin LB, Weil ZM, Nelson RJ. Seasonal tradeoffs between reproduction and immune activity. Philos Trans R Soc B 2008; 363: 321-339.

107.Lewinski A. Some aspects of pineal-thyroid interrelationships and their possible involvement in the regulation of function and growth of these two glands. Reiter RJ, Lukaszyk $\mathrm{K}$ editors. In: Advances in Pineal Research. John Libey \& Co Ltd. 175-188, 1990.

108. Haldar C, Shavali SS, Singh S. Photoperiodic response of pineal-thyroid axis of the female Indian palm squirrel, Funambulus pennant. J Neural Transm Gen Sect 1992; 90: 45-52.

109.Hassman RA, Lazarus JH, Dieguez, C, Weetman AP, Hall R. The influence of lithium chloride on experimental autoimmune thyroid disease. Clin Exp Immonol 1985; 61: 49 - 57.

110.Rai S, Haldar C, Singh SS. Trade-off between Lthyroxin and melatonin in immune regulation of the Indian palm squirrel, Funambulus pennanti during the reproductively inactive phase. Neuroendocrinol 2005; 82: 103-110.

111.Baroni CD, Fabris N, Bertoli G. Effects of hormones on development and function of lymphoid tissues, Synergistic action of thyroxin and somatotropic hormone in pituitary dwarf mice. Immunol 1969; 17: 303-314.

112. Weetman AP, McGregor AM, Ludgate M, Hall R. Effect of tri-iodothyronine on normal human lymphocyte function. J Endocrinol 1984;10: 81-86.

113. Gupta BB, Thapliyal JP. Role of thyroid and testicular hormones in the oxidative metabolism of the Indian garden lizard, Calotes versicolor. Gen Comp Endocrinol 1985; 58: 20-27.

114. Shavali SS, Haldar C. Effects of continuous light, continuous darkness and pinealectomy on pinealthyroid-gonadal axis of the female Indian palm squirrel, Funambulus pennant. J Neural Transm 1998; 105: 407-413.

115. Matera L, Mori M. Cooperation of pituitary hormone prolactin with interleukin-2 and interleukin-12 on production of interferon-gamma by natural killer and T cells. Ann N Y Acad Sci 2000; 917: 505-513.

116.Hermus AR, Sweep CG. Cytokines and the hypothalamic-pituitary-adrenal axis. J Steroid Biochem Mol Biol 1990; 37: 867-871.

117.Harbuz MS, Lightman SL. Stress and the hypothalamo-pituitaryadrenal axis: acute, chronic and immunological activation. $\mathrm{J}$ Endocrinol 1992; 134: 327-339.

118. Withyachumnarnkul B, Nonaka KO, Santana C, Attia AM, Reiter RJ. Inferferon-gamma modulates melatonin production in rat pineal glands in organ culture. J Interferon Res 1990; 10: 403- 411.

119.Kim CK, Turnbull AV, Lee SY, Rivier CL. Effects of prenatal exposure to alcohol on the release of adenocorticotropic hormone, corticosterone, and proinflammatory cytokines. Alc Clin Exp Res 1999; 23: 52-59.

120.Colombo N, Peccatori F, Paganin C, Bini S, Brandley M, Mangioni C, Mantovani A, Allavena P. Anti-tumour and immunomodulatory activity of intraperitoneal IFN-gamma in ovarian carcinoma patients with minimal residual tumor after chemotherapy. Int J Cancer 1992; 51: 42-46.

121.Salkowski CA, Vogel SN. Lipopolysaccharide increases glucocorticoid receptor expression in murine macrophages. A possible mechanism for glucocorticoid-mediated suppression of endotoxicity. J Immunol 1992; 149: 41-47.

122.Blalock JE. Shared ligands and receptors as a molecular mechanism for communication between the immune and neuroendocrine systems. Ann, NY Acad Sci 1994; 741: 292-298.

123. Chen HF, Jeung EB, Stephenson M, Leung PC. Human peripheral blood mononuclear cells express gonadotropin-releasing hormone (GnRH), GnRH receptor, and interleukin-2 receptor gamma-chain messenger ribonucleic acids that are regulated by GnRH in vitro. J Clin Endocr Metab 1999; 84: $743-750$

124.Tolosa E, Ashwell JD. Thymus-derived glucocorticoids and the regulation of antigenspecific T-cell development. Neuroimmunomod 1999; 6: 90-96. 